\title{
CONSTRUCTION OF TRAINING PROCESS OF TENNIS PLAYERS AGED 5-6 YEARS, TAKING INTO ACCOUNT THE SPECIFICS OF THE DEVELOPMENT AND CONTROL OF THEIR COORDINATION SKILLS
}

Kozak A. M., Ibraimova M. V.

National University of Physical Education and Sport of Ukraine

\begin{abstract}
Annotation. Purpose: Presented results of the research to determine the features of the construction of the training process for young tennis players aged 5-6 years, in particular the specific application of pedagogical testing to test the level of development of their coordination skills. Material: The survey was attended by 30 experts. Results: Established that bigger part of coaches build the training process at the initial stage of preparation on the basis of the game approach and apply a program of the International Tennis Federation "Play and stay". About two-thirds of the coaches do not carry out a selection of tennis players aged 5-6 or make it only in individual cases. To assess the level of development of motor abilities are equally important coaches define pedagogical supervision and pedagogical testing. A significant proportion of respondents (43\%) previously had experience in assessing motor abilities of tennis players 5-6 years by mean of pedagogical tests. Conclusions: Overwhelming majority of coaches support the idea of having to modify the tests in accordance with the age characterristics of tennis players aged 5-6 years and expediency of complex assessment of the level of development of their coordination skills.
\end{abstract}

Key words: tennis, testing, coordination abilities, complex control, tennis players.

\section{Introduction}

Currently, new requirements produced in respect of the construction of the training process, the selection to sports schools, the diagnosis of various aspects of the development and preparedness of young sportsmen. Accordingly, many specialists and coaches have questions, answers for which it is possible to get only as a result of the special researches.

Today greater amount of parents engage the children in sport schools and clubs on tennis from the earliest age. This tendency, caused by changes in tennis Curriculum for Sport Tennis Schools now oriented to experience of international researches in child's tennis [12].

By some authors have developed and proposed for use the methodology and complexes exercises for teaching children 4-6 years $[4,6,11]$, and studied their influence on the improvement of the functional systems of the body, motor skills, physical development $[3,7,13,14]$. Today is absent publication about the diagnosis level of coordination - key ability for children of this age to effectively teach basic technical skills of tennis. Coordination abilities are also an important criterion for the selection and the future orientation young athletes in tennis.

Study the features of diagnosing the level of coordination abilities tennis players 5-6 years will contribute to the effective selection young tennis players and a differentiated approach to the rational construction of the training process at the initial stage of preparation.

In the Curriculum for Sport Tennis Schools 2012 [12] the construction of the initial stage preparation is based on 3 levels learning tennis: "red", "orange" and "green." Levels are derived from the names of colors and special compression balls, the size of the playing area, which take into consideration the age characteristics younger school children.

In initial preparation groups of the 1 st year of study ("red" tennis level) executed the selection of capable children for further specialization in tennis. Because of this aim, there are complex of organizational and methodical actions, in a result of which carry out viewing as possible greater amount of active children. Coaches fix special abilities, which are needed for tennis player, reveal compliance physical, technical and psychological readiness of children, that engage in the initial preparation groups, to normative requirements $[5,12]$.

According to the training program (Curriculum) Sport Tennis Schools can engage children 5-6 years (10 people in the group). Children can distribute into several subgroups by coaches, according to various criteria: age, gender, level of physical development, mental characteristics, the level of physical and especially - coordination abilities [5,12].

As before children began engaging tennis from seven, there was not significant necessity for determination the level of developing coordination abilities 5-6 years old children, but now this question looks actually enough. The level of developing coordination abilities can become one of the key criteria for the differentiated approach to education and for passing to the next stage of preparation.

Data trainers questioning shows that majority of them consider, that coordination abilities is major physical ability for education the basic tennis skills. As well-known researchers mark, many of relatively independent types of coordination abilities have sensitive periods of development, that fall on the stage of initial preparation in tennis [2,5,8]. By A.S. Solodkov and E.B. Sologub [10], in the basic motor structure of 3-6-years-old children coordination abilities amount $52-57 \%$. To the coaches, that are training preschoolers, it is important to know about so-called «slow» children which require the special approach to development motor abilities, including coordination [10]. In particular, by results of children's pedagogical testing of this age it is expedient to plan the proper tasks and create (if it is necessary) a separate sub-group for effective development more capable children. 
Purpose, tasks of the work, material and methods

The aim of this research is to determine the characteristics of the construction of the training process for tennis players 5-6 years as a result of the survey of coaches.

Methods and organization studies. Methods were follows: study and analysis of literary and documentary materials about the problem of research, pedagogical observation, survay. The study involved 30 tennis coaches - 15 men and 15 women, the large majority of them - 90\% - had direct experience of engaging with children 5-6 years of age. Another $10 \%$ worked with tennis players of groups of initial preparation 2-3 year of study. The average age of respondents was $30 \pm 8,9$ years, and the average duration of their work $-9 \pm 6,7$ years.

\section{Results of the research}

The importance of coordination abilities to play tennis and branching their structures necessitate integrated control of all relatively independent kinds this physical quality of young tennis players [1,2,8,9]. As long as the development of coordination abilities begins mainly in the stage of initial preparation, it becomes relevant to determine the level of it development in young athletes. Coaches poll was conducted in order to supplement information obtained from the analysis of literature and pedagogical observations about the features of the control of coordination abilities of children of 5-6 years on the stage of initial preparation in tennis.

Almost half of polled coaches (47\%) train tennis groups of the first year initial preparation, in which the number of children exceeds the minimum rate. This figure indicates that at present there is a big demand for tennis lessons. Almost half of the coaches (47\%) has experience with preschool children 5-6 years old, engaging with more than one group, and may offer the optimal modern training program considering the age of the children.

The amount of specialists which teach young sportsmen playing tennis is lately increased, using offered the International Tennis Federation program «Play and remain in tennis forever» («Play \& Stay») or some elements of this program to which, foremost, belongs varying of playground's sizes, rackets, index of compression of balls, and also rules of game on an account depending on age and individual possibilities of players.

All these innovations are called to improve the process of teaching of tennis players on the stage of initial preparation and bring over as many as possible children to employments by sport. In this connection, was detected opinion of coaches about application of the program «Play \& Stay» in training children under age 10 years.

On fig. 1 shown results of coach's survey about applying new presented program on children's training in Sport

Tennis Schools.

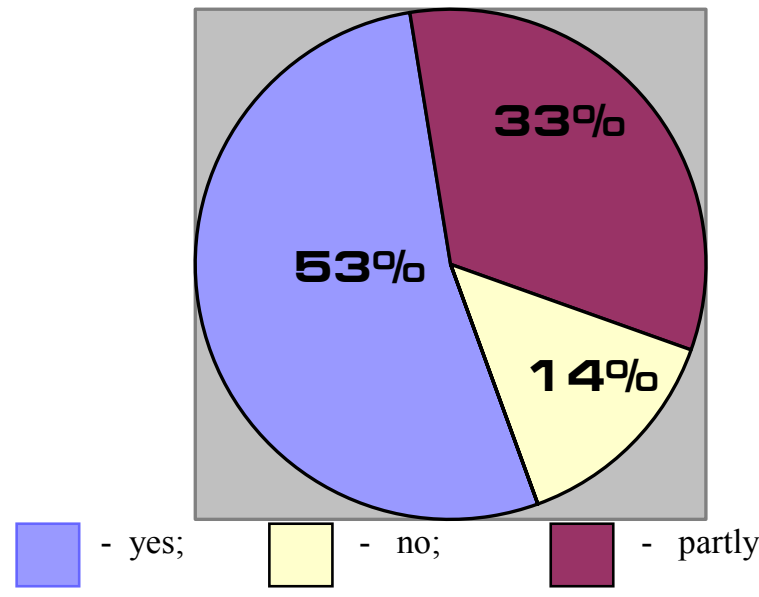

Picture 1. Application of the program «Play and remain in tennis forever» («Play \& Stay») by coaches in-process with children in Sport Tennis Schools.

Playing approach as a key component of the presented program of development young player on the initial stage is basis to increase motivation of children and their harmonious development. He supposes not only the use of different mobile games but also that in a playing form it is possible to conduct a whole tennis lesson, which consists of different interesting tasks which a trainer presents children as a game, often using different images and associations.

During the lesson there is alternation of playing tasks (mobile games and relay races), directed on development of motor skills, physical qualities (coordination, speed and speed-power capabilities, aerobic endurance), that provides high dynamic quality of lesson. On a fig. 2 the results of questioning of coaches are indicate on application by them playing approach in training process. So, $77 \%$ polled coaches apply playing approach during employments, $23 \%-$ use such approach from time to time, and none of respondents specified that does not takes it into account. 


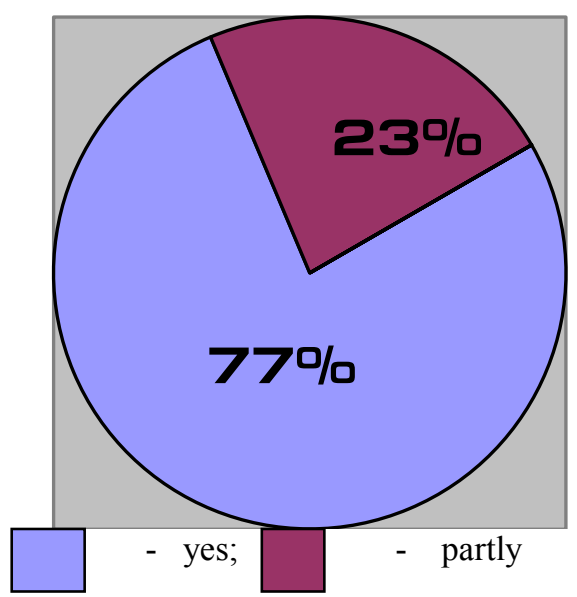

Picture 2. Application of play approach by coaches to teaching young tennis players on the stage of initial preparation.

It testifies about understanding of key role of play approach by coaches to teach tennis exercises children of preschool and junior school age, about their knowledge the mental features of children at the construction of training process on the stage of initial preparation.

Considering the indicated initial age for tennis employments and duration of the stage of initial preparation, the enough actual is become a question about expedience of selecting children 5-6 years for employments by this type of sport.

Outspoken opinions by trainers in the poll in relation to expedience of selection of 5-6-years children for tennis employments distributed as follows: $30 \%$ agree with his necessity, 30\% acknowledge necessary to select only on occasion, and $40 \%$ does not consider his expedient in this age (fig. 3 ).

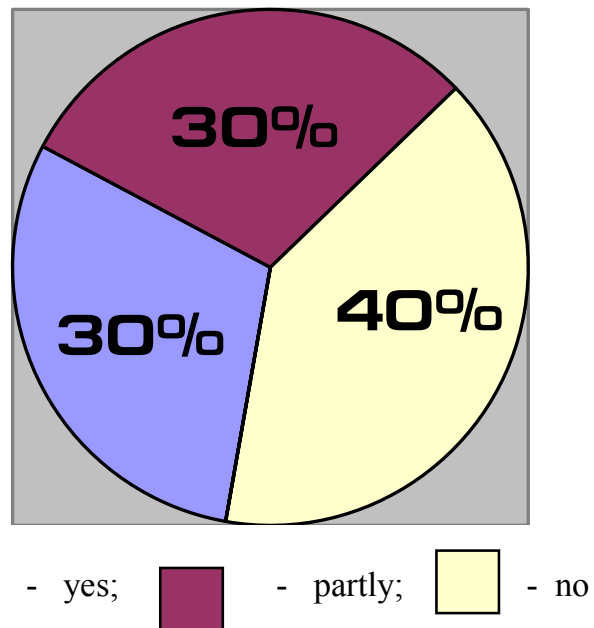

Picture 3. Expedience of selection 5-6 years children for tennis employments on the stage of initial preparation.

As is generally known from researches of many scientists [2,5,8,12], the stage of initial preparation is major for development of physical qualities. On results questioning most coaches is estimated level of development of physical qualities by a pedagogical supervision $-53 \%$, and pedagogical testing $-47 \%$ (fig. 4). Thus, almost the half of respondents is well-informed about the specific of maintenance and method of leadthrough of control children's physical abilities. 


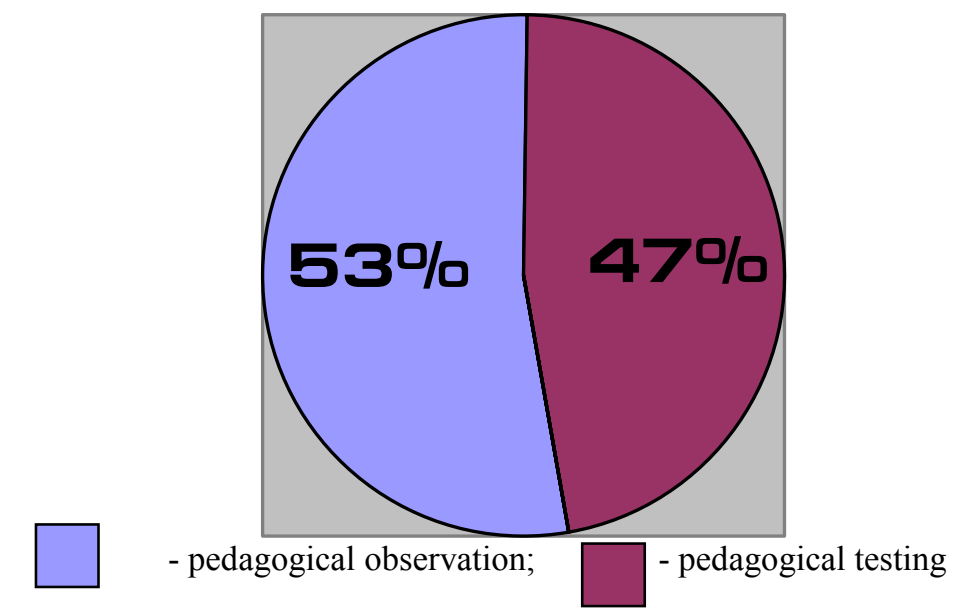

Picture 4. Basic methods of estimation motor abilities of young tennis players on the stage of initial preparation.

However, taking into account the real initial age of employments tennis (5 years), there is a question about expedience of the use of standard test tasks for tennis preschool players. On a fig. 5 the results of determination of coach's opinion are rotined about expedience of the use test tasks for determination the level of physical preparedness 5-6 years children, engaged in tennis.

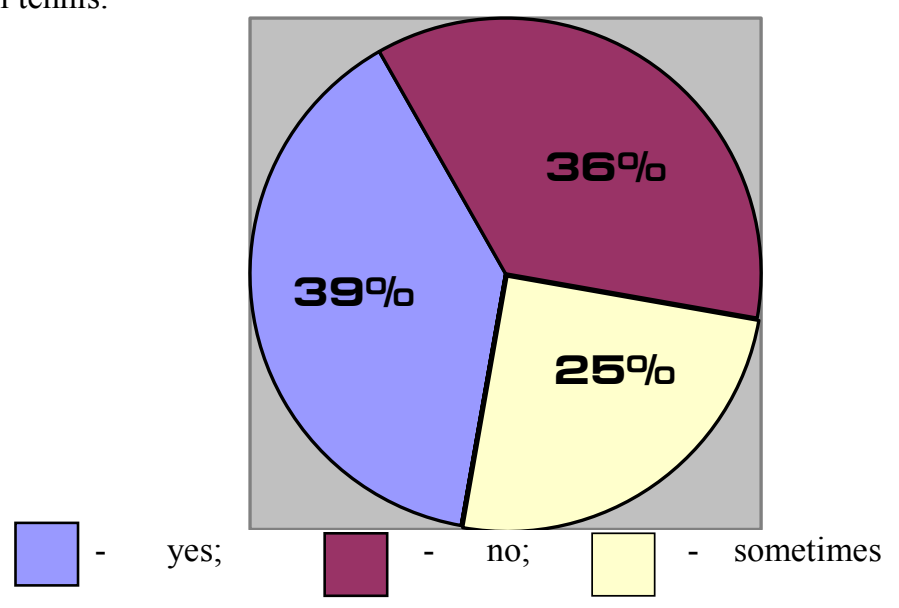

Picture 5. Expedience of the use test tasks by coaches for determination the level of physical preparedness of tennis players 5-6 years.

$39 \%$ polled specialists estimate practice of the pedagogical testing positively, $36 \%$ does not count its expedient, and $25 \%$ guess that application of testing for the selection children to employments on a first year of study is possible only under favourable circumstances. Favourable circumstances, in their opinion, is an enough amount of time for plugging of testing in the program of reading with the large group of children, without violation process of decision the planned tasks. In training process, when present the proper equipment, that use in a test, quality theoretical and methodical preparedness of coach - is possible the leadthrough of control different types of physical qualities of children 5-6 years. These circumstances are stipulated by the followings results of questioning about estimation by coaches the level of development of coordination capabilities children 5-6 years with the purpose of selection in the groups of initial preparation through the pedagogical testing: the $43 \%$ polled conduct the pedagogical testing as a rule, and $57 \%-$ no (fig. 6). 


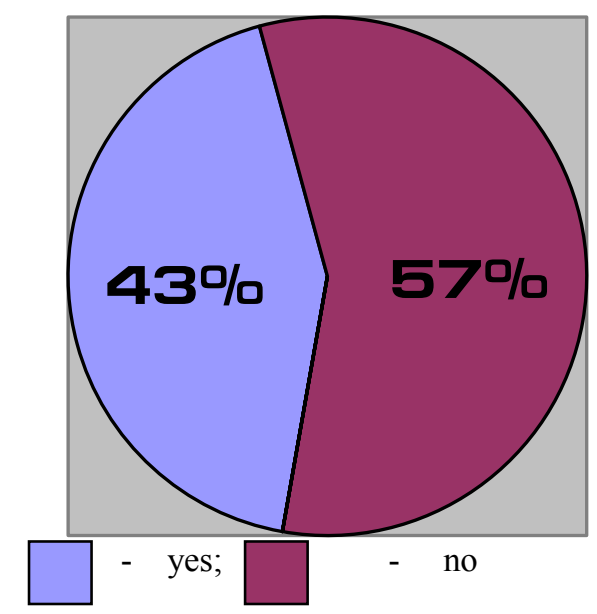

Picture 6. Application of pedagogical tests by trainers for determination the level of development coordination abilities of children 5-6 years.

Some of the known tests, developed before by specialists and approved in practice of training the children of school age can be difficult for implementation 5-6-years-old tennis players. On the indexes, it is impossible exactly to say about the level of the probed physical quality. For example, in the test of Filipovich-Malinak [9] comparison of speed at run in ordinary and complicated terms on segments accordingly $30 \mathrm{~m}$ and $3 \times 10 \mathrm{~m}$ will not show in the same degree the level of development of coordination abilities for preschoolers, and for children middle and senior classes. At the same time, at run on proportionally brief segments $12 \mathrm{~m}$ and $3 \times 4 \mathrm{~m}$ in this test, at first, will allow 5-6 years players to retain high speed on all distance, and in the second, will anymore correspond the standards of tennis ground at «red» level of tennis $-12 \times 6 \mathrm{~m}$. For this reason modification of some tests becomes actual for determination the level of development coordination abilities by adaptation their spatial and temporal descriptions, level of motor complication to age-dependent possibilities of tennis players 5-6 years old.

Swingeing majority (93\%) of coaches was supported such suggestion, and not see a necessity for modifications test tasks for children 5-6 years only 7\% polled, that is rotined on a fig. 7.

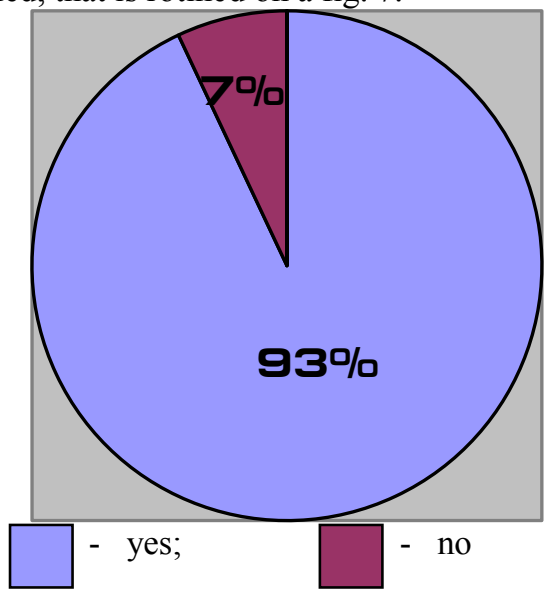

Picture 7. Necessity of modification tests that applying by coaches for determination the level of development coordination abilities 5-6 years children.

Among the polled coaches $70 \%$ accede to the necessity of complex estimation of coordination abilities, and $30 \%$ - does not insist on it. From data of survey the level of actually of different relatively independent kinds of coordination abilities was certain at teaching children to tennis and competition activity, level of influence different factors on the indexes the development of coordination abilities of sportsmen. Positive opinion of trainers had determined in relation to expedience of leadthrough the complex testing of coordination abilities of tennis players 5-6 years, that will increase efficiency of selection and control on the stage of initial preparation in tennis.

\section{Conclusions.}

Most trainers use the modern program of the International Tennis Federation «Play \& Stay» during training process the children and actively apply play approach during training employments. Specialists of tennis (30\% trainers) deem it wise to select tennis players 5-6 years, 30\% respondents acknowledge necessary to select only on occasion, and $40 \%$ does not consider his expedient in this age. The methods of pedagogical supervision and pedagogical testing apply for a selection, as a rule. Part of trainers does not consider it necessary to apply the estimation of physical abilities of children 5-6 years and does not apply the method of the pedagogical testing for determination the level of development of their coordination abilities (53\%), however such practice estimated by many trainers (47\%) positively. Swingeing 
majority of specialists (70\%) acknowledge importance of complex estimation of coordination abilities of tennis players 5-6 summer age and accede to suggestion of modification of different test's parameters in accordance with age of student $(93 \%)$. The most polled is counted, that leadthrough of the pedagogical testing 2 times in a school year optimum. Thus, in opinion of most trainers, it is necessary to use 2 tests for the estimation the level of development in relation to the independent kinds of coordination abilities.

Prospect of further researches. Researches the level of development coordination abilities, related to their complex estimation for tennis players on the stage of initial preparation, considering modern approaches, will matter very much and will help coaches more rationally plan content of physical preparation. Application of the differentiated approach to teaching of young tennis players will allow to promote efficiency of training process on the initial stage of preparation.

\section{References:}

1. Bernshtejn N.A. O lovkosti i ee razvitii [On dexterity and its development], Moscow, Physical Culture and Sport, 1991, $228 \mathrm{p}$.

2. Volkov L.V. Teoriia i metodika detskogo i iunosheskogo sporta [Theory and methods of youth sport], Kiev, Olympic Literature, 2002, 294 p.

3. Zhuravleva A.Iu. Fizicheskaia kul'tura: vospitanie, obrazovanie, trenirovka [Physical education: upbringing, education, training], 2011, vol.6, pp. 42-47.

4. Zhuravleva A.Iu., Zajceva L.S. Fizicheskaia kul'tura: vospitanie, obrazovanie, trenirovka [Physical education: upbringing, education, training], 2008, vol.4, pp. 34-35.

5. Ibraimova M.V., Khaniukova O.V., Polishchuk L.V. Suchasna shkola tenisu [Modern tennis school], Kiev, Express, 2013, 204 p.

6. Kurmaieva Ie.V. Pedagogika, psihologia ta mediko-biologicni problemi fizicnogo vihovanna i sportu [Pedagogics, psychology, medical-biological problems of physical training and sports], 2014, vol.6, pp. 21-25.

7. Loboda V.S., Mulik Z.V., Duzhina L.V. Slobozhans'kij naukovo-sportivnij visnik [Slobozhanskyi Herald of Science and Sport], 2012, vol.2 (37), pp. 51-55.

8. Liakh V.I. Koordinacionnye sposobnosti [Coordination abilities], Moscow, TBT Division, 2006, 290 p.

9. Sergiienko L.P. Testuvannia rukhovikh zdibnostej shkoliariv [Testing of motor abilities of students], Kiev, Olympic Literature, 2001, 439 p.

10. Solodkov A.S. Fiziologiia cheloveka [Human physiology], Moscow, Olympia Press, 2005, 528 p.

11. Suprunenko M.V. Visnik Chernigivs'kogo derzhavnogo pedagogichnogo universitetu [Bulletin of the Chernihiv State Pedagogical University], 2010, vol.81, pp. 447-451.

12. Grishko L.G. Tenis [Tennis], Kiev, RNMK, 2012, 160 p.

13. Shevchenko O.A. Slobozhans'kij naukovo-sportivnij visnik [Slobozhanskyi Herald of Science and Sport], 2013, vol.4(37), pp. 111-114.

14. Iakubovskij V.S., Iakubovskij G.S., Ivanova T.S. Fizicheskaia kul'tura: vospitanie, obrazovanie, trenirovka [Physical education: upbringing, education, training], 2012, vol.6, pp. 71-72.

15. Borisova O. V. Tennis: history and the present. Pedagogics, psychology, medical-biological problems of physical training and sports. 2012, vol.11, pp. 119-124.

16. Emshanova Y.O., Comparative analysis of individual peculiarities for tennis players of different qualification. Physical Education of Students, 2013, vol.4, pp. 23-26. doi:10.6084/m9.figshare.662589

17. Jagiello Marina, Jagiello Wladyslaw. Final preparations to the girls' tennis europe junior masters. Physical Education of Students, 2014, vol.5, pp. 59-64. doi:10.15561/20755279.2014.0511 
Information about the authors:

Kozak A.M.: ORCID: http://orcid.org/0000-0002-3509-1243; kozakIv@yandex.ru; National University of Physical Education and Sport of Ukraine; Fizkultury str. 1, Kiev, 03680, Ukraine.

Ibraimova M.V.: ORCID: http://orcid.org/0000-0002-1023-6506; tennis-m@ukr.net; National University of Physical Education and Sport of Ukraine; Fizkultury str. 1, Kiev, 03680, Ukraine.

Cite this article as: Kozak A. M., Ibraimova M. V. Construction of training process of tennis players aged 5-6 years, taking into account the specifics of the development and control of their coordination skills. Physical education of students, 2014, vol.6, pp. 17-23. doi: $10.15561 / 20755279.2014 .0604$

The electronic version of this article is the complete one and can be found online at: http://www.sportpedu.org.ua/html/arhive-e.html

This is an Open Access article distributed under the terms of the Creative Commons Attribution License, which permits unrestricted use, distribution, and reproduction in any medium, provided the original work is properly cited (http:// creativecommons.org/licenses/by/3.0/deed.en)

Received: 10.06.2014

Published 30.06 .2014 